\title{
Sneddon's Syndrome (Livedo Racemosa and Cerebral Infarction) Presenting Psychiatric Disturbance and Shortening of Fingers and Toes
}

\author{
Masaaki Kume, Hirokazu Imai, Mutsuhito Motegi, Akira B. Miura and Ikuro Namura*
}

\begin{abstract}
A 24-year-old man with livedo racemosa and psychiatric disturbances, manifesting as low intelligence (IQ 80) and delusions, had anti-cardiolipin antibody and showed shortening of the fingers and toes. A skin biopsy of the livedo lesion revealed endoarteritis obliterans, being compatible with Sneddon's syndrome. MRI of the brain demonstrated multiple infarction and moderate cortical atrophy. A single photon emission tomography of the brain showed a marked reduction of the blood flow in the front-temporal lobe. These findings might relate to the psychiatric disturbance. After intravenous administration of cyclophosphamide and the start of oral prednisolone, the anti-cardiolipin antibody level decreased and his physical condition improved. However, a low dose of haloperidol is still necessary to maintain his mental condition.
\end{abstract}

(Internal Medicine 35: 668-673, 1996)

Key words: livedo, endoarteritis obliterans, psychiatric disturbance, anti-cardiolipin antibody

\section{Introduction}

Livedo racemosa is a cutaneous condition resulting from an irregular, focal, and persistent impairment of the blood flow due to atherosclerosis or vasculitides. The association between livedo racemosa and cerebrovascular manifestation was first described by Kimming (1) in 1959. Champion and Rock (2) and Church (3) also reported similar cases. In 1965, Sneddon (4) described six patients with this combination including Church's case. He speculated that this disorder was a type of endoarteritis obliterans. Subsequently, this combination came to be known as Sneddon's syndrome because there are no signs of polyarteritis nodosa, systemic lupus erythematosus, rheumatoid arthritis, or other definite systemic diseases. Regarding the pathogenesis of this syndrome, the importance of anti-phospholipid antibodies has been emphasized. However, the incidence of positive anti-phospholipid antibodies in conventional methods varies from $20 \%$ (5) to almost $60 \%$ (6). Other factors may also induce Sneddon's syndrome. The incidence of this syndrome has been estimated at $0.26 \%$ of the total cerebrovascular disease cases (7). Although more than one hundred cases have been reported over the world, we could find only three previous cases reported in Japan (8-10). Here, we report a case of Sneddon's syndrome in which the patient has a circulatory anti-cardiolipin antibody, psychiatric symptoms, and shortening of fingers and toes, and we discuss about the therapy and review the existing literature.

\section{Case Reports}

A 24-year-old man was admitted to Akita University Hospital because of psychiatric problems, livedo racemosa, and shortening of his fingers and toes on January 12, 1995. He had been suffering from facial erythema and frostbite of the extremities since he was one year old. At the age of seven and nine, he was admitted to the pediatric department of our hospital due to livedo on his extremities and trunk, and facial erythema. Laboratory tests revealed a high level of erythrocyte sedimentation rate, hypergammaglobulinemia, and a low titer of antinuclear antibody. A skin biopsy of the livedo lesion revealed a constricted artery occluded with cellular and humoral components, a thickened endothelium, and small round cells which had infiltrated around the vessels (Fig. 1). Physical examination and laboratory data of patient and his mother denied congenital

From the Third Department of Internal Medicine and *the Department of Psychiatry, Akita University School of Medicine, Akita Received for publication February 5, 1996; Accepted for publication May 21, 1996

Reprint requests should be addressed to Dr. Hirokazu Imai, the Third Department of Internal Medicine, Akita University School of Medicine, 1-1-1 Hondo, Akita 010 
syphilis. After a diagnosis of thromboangiitis was made, he was treated with vasodilators, anticoagulant drugs, and a small dose of prednisolone. However, Raynaud's phenomenon and the shortening of his fingers and toes gradually advanced. At the age of 20, he complained of a feeling of being watched and controlled by a TV camera. A psychiatrist made a diagnosis of psychotic state with hallucinations and delusions. His condition gradually worsened. The total clinical course is summarized in Fig. 2. Although his family history revealed that his mother has been treated for schizophrenia, her cerebral MRI was normal and anti-cardiolipin antibody was negative. His grandfather had hypertension and dementia. A physical examination showed a deformity of the auricles and shortness and deformity of the fingers and toes (Fig. 3). X-ray films of the hands showed phalangeal tuftal resorption, which is similar to the finding of progressive systemic sclerosis (PSS). The lungs, heart and abdomen appeared normal. The right patellar reflex has disappeared and a tremor of both arms was observed. Psychological tests revealed a mild mental retardation.

Laboratory tests disclosed that the erythrocyte sedimentation rate was $35 \mathrm{~mm} / \mathrm{hr}$, the antinuclear antibody was 80 fold, and the anti-cardiolipin antibody (IgG-class) was $1.7 \mathrm{U} / \mathrm{ml}$ (normal range: below 1.0). However, the anti-cardiolipin $\beta_{2}$ glycoprotein 1 antibody was negative. Other laboratory data were as follows: WBC 5,700/ $\mu \mathrm{l}, \mathrm{Hb} 14.0 \mathrm{~g} / \mathrm{dl}$, platelets 192,000/ $\mu 1$, AST $26 \mathrm{U} / l$, ALT $32 \mathrm{U} / l, \mathrm{LDH} 142 \mathrm{U} / l$, BUN $10 \mathrm{mg} / \mathrm{dl}$, UA $5.8 \mathrm{mg} / \mathrm{dl}$, creatinine $0.8 \mathrm{mg} / \mathrm{dl}$, APTT 41 seconds (normal range: 29-44), PT $11 \mathrm{sec}$ (normal range: 10.3-12.4), TT 100\%, FDP $2.1 \mu \mathrm{g} / \mathrm{ml}$, fibrinogen $324 \mathrm{mg} / \mathrm{dl}$, AT-III $84 \%$, $\alpha 1$-plasmin inhibitor $86 \%$, plasminogen $91 \%$. CRP was $0.2 \mathrm{mg} / \mathrm{dl}$ (normal range: below 0.3), C3 was $64 \mathrm{mg} / \mathrm{dl}$ (normal range: 60-119), C4 was $21 \mathrm{mg} / \mathrm{dl}$ (normal range: 16-43), CH50 was $31 \mathrm{U} / \mathrm{ml}$ (normal range: $30-50$ ).

Magnetic resonance imaging of the brain revealed various abnormal findings: multiple small infarctions within the cerebral cortex (arrows in Figs. 4 and 5), subcortical white matter lesions mainly shown as $\mathrm{T} 2 \mathrm{high}$ intensity areas (arrow heads in Fig. 5), periventricular T1 low and T2 high intensity region, especially adjacent to the anterior horn, T1 low and T2 high spots in basal ganglia and deep white matter which probably indicates widened perivascular (Virchow-Robin) space and/or necrosis in the surrounding area, moderate widening of subarachnoidal space and sulcus dilatation predominantly in the front-temporal region, moderate widening of Sylvian fissure associated with temporal pole atrophy, dilatation of the third ventricle and cavum vergae. Single photon emission tomography of the brain revealed a severe decrease of the blood perfusion mainly in the left front-temporal lobe. We made a
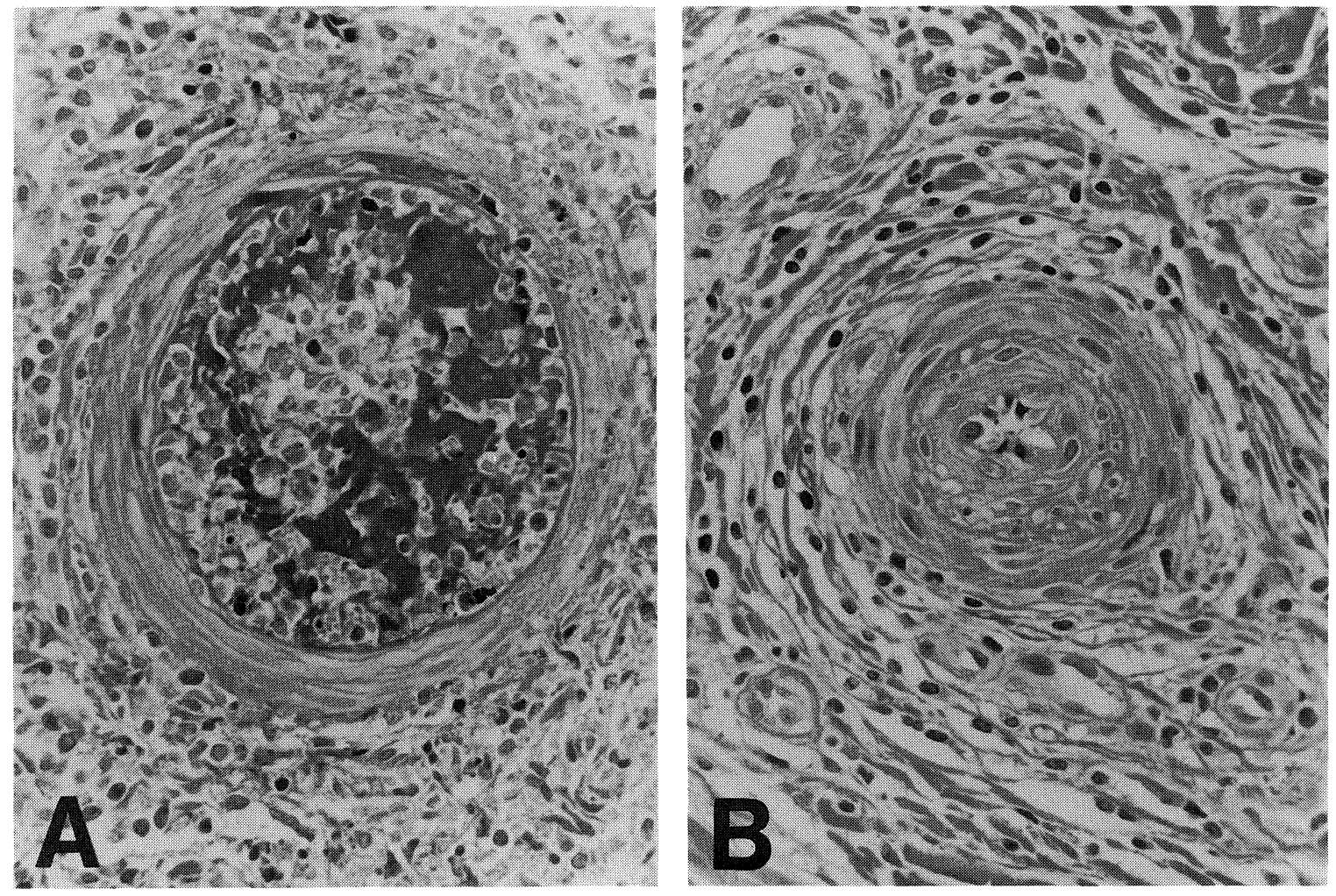

Figure 1. Light microscopic studies of the skin biopsy. A) The constricted artery was occluded with cellular and humoral components, and small round cells infiltrated the artery (HE stain, $\times 400)$. B) The prominent proliferation of intimal cells shows an onion-skin lesion at the arteriole-level. Small round cells and fibrotic cells were also observed around the vessels $($ HE stain, $\times 400)$. 


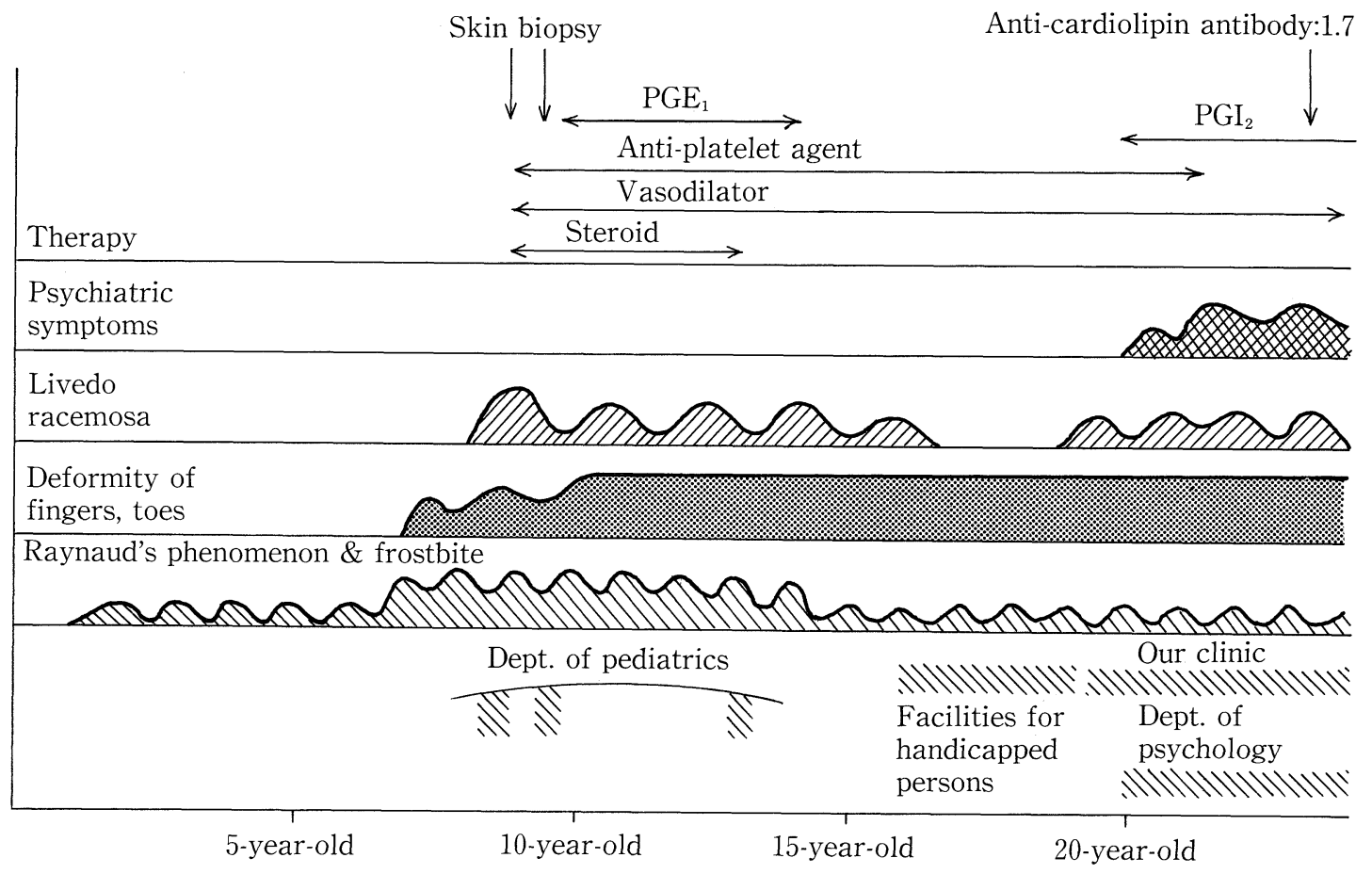

Figure 2. Complete clinical course.
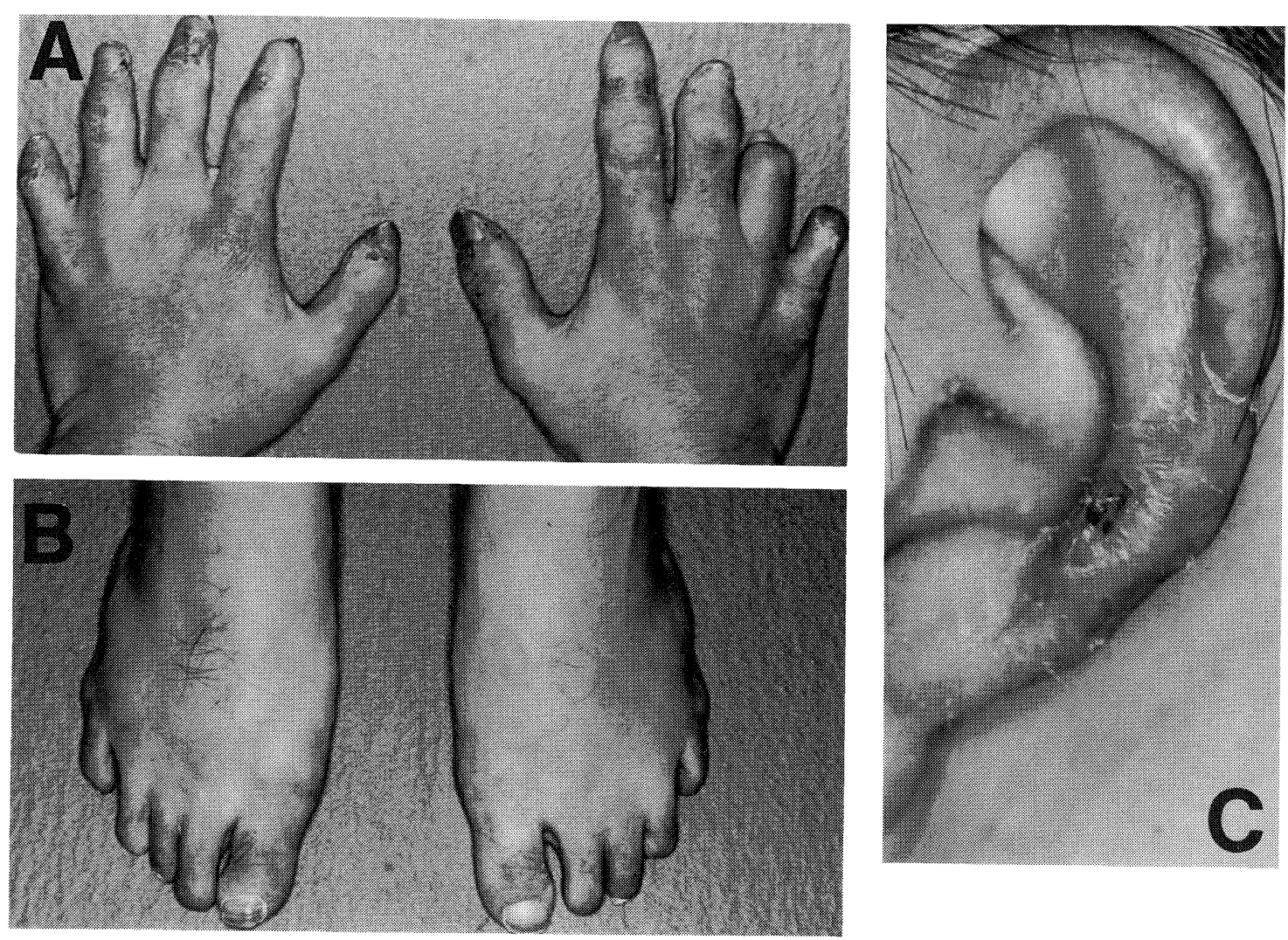

Figure 3. The deformity of fingers (A), toes (B), and the left auricle (C). 

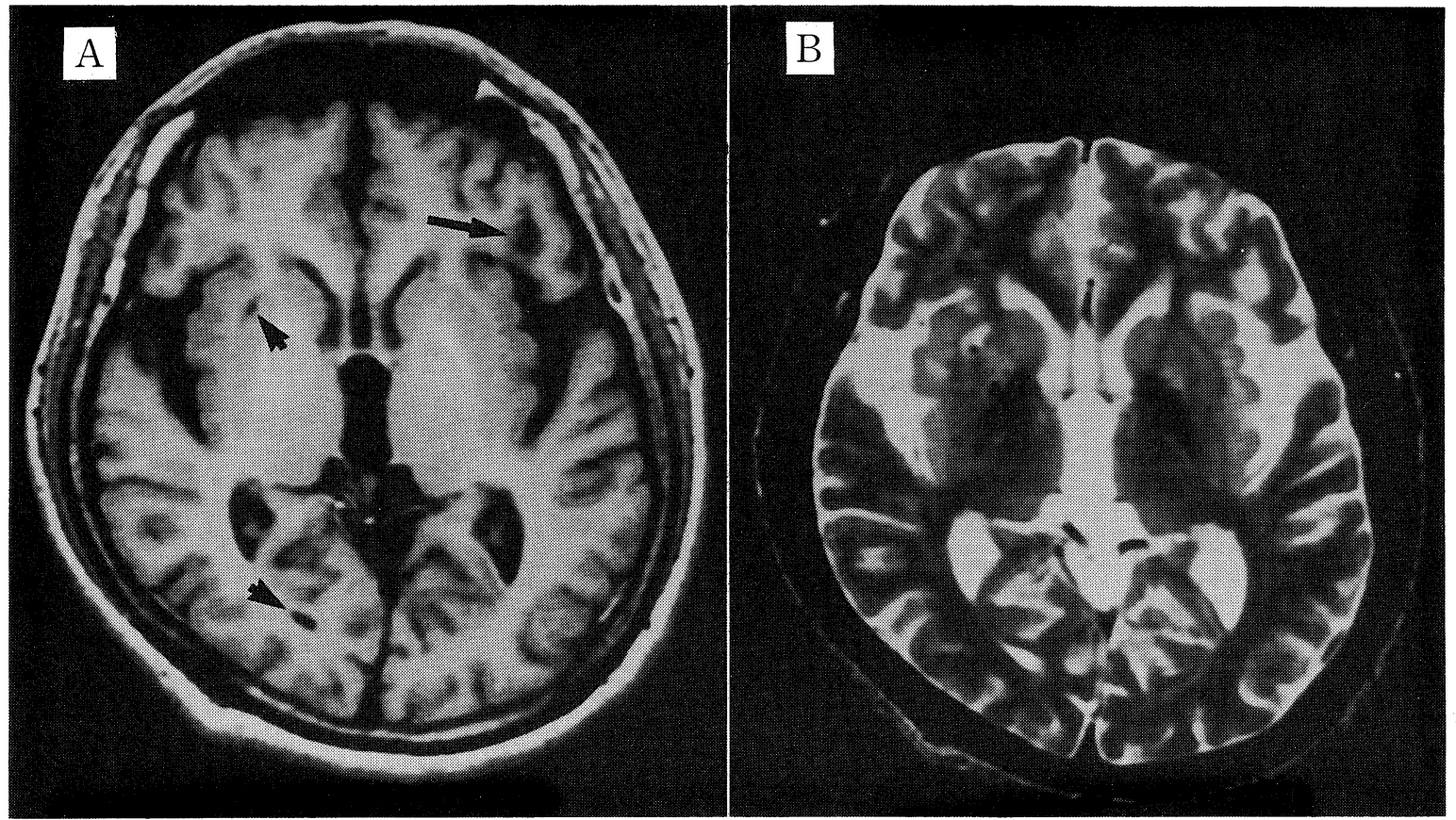

Figure 4. Cerebral MRI images of the case. A small cortical infarction in the left frontal lobe is shown as low signal area in the $\mathrm{T} 1$ weighted image (arrows). Low intensity spots in $\mathrm{T} 1$ image are also seen in the basal ganglia and in deep white matter (arrowheads). A) T1 weighted image, TR/TE $=440 / 13 \mathrm{msec}, \mathrm{B}$ ) heavily $\mathrm{T} 2$ weighted image, TR/ $\mathrm{TE}=4,200 / 100 \mathrm{msec}$.
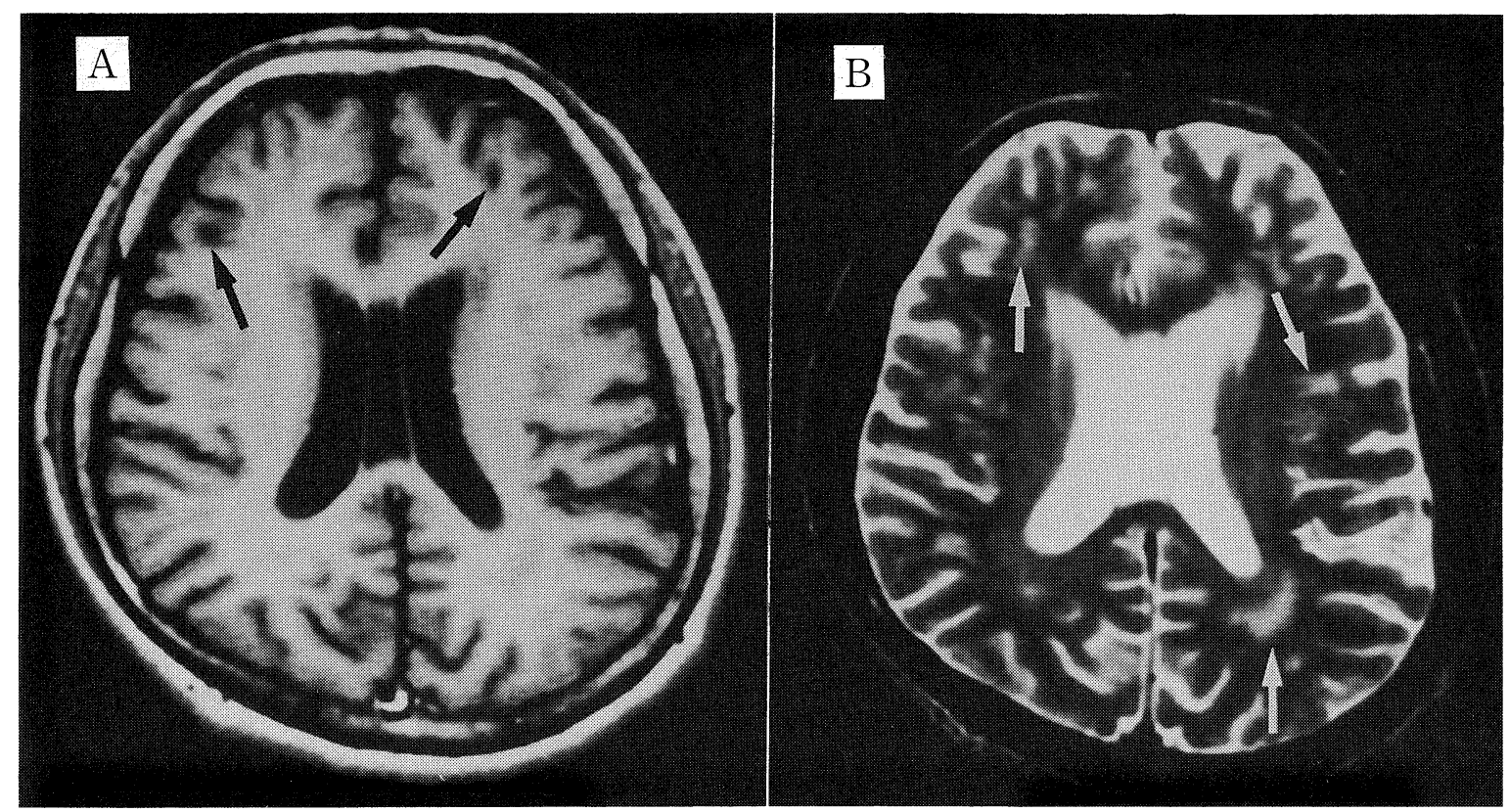

Figure 5. MRI images of the case. Horizontal MRI images through the body of the lateral ventricle. A) T1 weighted image shows multiple spotty cortical infarction (arrows). B) T2 weighted image of the same level reveals widened subarachnoid space, and multiple high intensity areas and spots in the deep white matter (white arrows). 
diagnosis of Sneddon's syndrome, due to the multiple cerebral infarction and cerebral atrophy which manifested as a psychiatric disturbance, in addition to livedo racemosa which was detected by a skin biopsy on his previous admission. The patient was then given an intravenous treatment of cyclophosphamide twice $(400 \mathrm{mg} /$ day, biweekly), $20 \mathrm{mg} /$ day of prednisolone orally, and $60 \mu \mathrm{g} / \mathrm{day}$ of prostaglandin $\mathrm{I}_{2}$ analogue orally. His physical symptoms gradually improved and the titer of anticardiolipin antibody (IgG-class) decreased to below $1.0 \mathrm{U} / \mathrm{ml}$. However, a low dose of haloperidol (1-2 mg/day) is still necessary to maintain his mental condition.

\section{Discussion}

The combination of livedo racemosa and cerebrovascular disease is known as Sneddon's syndrome (4). Sneddon commented that the essential feature of this disease is endoarteritis obliterans. Recently, Zelger et al (11) demonstrated pathological changes in the cutaneous vascular lesions. They studied 15 cases of Sneddon's syndrome and divided the disease into four stages: the initial phase (endothelitis), the early phase (complete arterial occlusion by a sponge-like plug of mononuclear cells), the intermediate phase (subendothelial cell proliferation), and the late phase (distortion and splitting of the lamina elastica interna). In the present case, the skin biopsy specimen, performed when he was fourteen, revealed both the early and intermediate phases of Sneddon's syndrome. The shortening of the fingers and toes, shown by phalangeal tuftal resorption on $\mathrm{X}$-ray studies, would relate to these findings of small arteries.

Regarding the pathogenesis of this disease, Jonas et al (12) suggested the important role of anti-phospholipid antibodies. Subsequently, this syndrome has come to be thought as a variant of primary anti-phospholipid antibody syndromes.
However, the percentage of anti-cardiolipin antibody or lupus anticoagulant varies between $20 \%$ and $60 \%(5,6)$. Patients with neither anticardiolipin antibody nor lupus anticoagulant have also been observed. The present patient has IgG-class anticardiolipin antibody, which suggests a variant type of antiphospholipid antibody syndrome. As for other factors on the progression of the endothelitis or endoarteritis, Otoyama et al (8) demonstrated that the serum of such patients reacts with ethanol-fixed endothelial cells, keratinocytes and peripheral blood neutrophils. A further study will clarify the pathogenesis of Sneddon's syndrome. Although more than one hundred cases have been reported in the world, we could find only three previous cases reported in Japan (8-10). We summarize four Japanese cases including our own (Table 1).

There are three unique points in the clinical course of the present patient. The first was the fact that the initial symptoms occurred as early as only one year old. At the age of 9 , the skin lesions were already compatible with the early or initial phase of Sneddon's syndrome. The average age of patients diagnosed as Sneddon's syndrome is 42 years; the present case is the youngest reported in the literature. The second point was the shortening of his fingers and toes (phalangeal resorption), which is sometimes observed in patients with progressive systemic sclerosis (PSS). However, even though he complained of Raynaud's phenomenon and frostbite, there were no signs of proximal skin sclerosis, pulmonary fibrosis, and esophageal dilatation; the lack of antibodies to scl-70 or centromere or nRNP ruled out the possibility of PSS or mixed connective tissue disease. The third point was that psychiatric problems were the predominant clinical manifestations of cerebrovascular lesions. He did not have a transient ischemic attack or hemiparesis due to the occlusion of the small or medium-sized arteries, which are frequent signs of Sneddon's syndrome. The size of the

Table 1. A Comparison of Japanese Patients with Sneddon's Syndrome

\begin{tabular}{|c|c|c|c|c|c|c|c|}
\hline Author & Age/Sex & $\begin{array}{l}\text { Age at initial } \\
\text { sign }\end{array}$ & Initial sign & $\begin{array}{l}\text { Age at } \\
\text { cerebro- } \\
\text { vascular } \\
\text { signs }\end{array}$ & $\begin{array}{l}\text { Cerebro- } \\
\text { vascular signs }\end{array}$ & $\begin{array}{l}\text { Brain CT or } \\
\text { MRI }\end{array}$ & $\begin{array}{l}\text { Anti-cardiolipin } \\
\text { antibodies }\end{array}$ \\
\hline Otoyama K (8) & $22 /$ female & $20-y-0$ & Leg ulcer & $22-y-0$ & $\begin{array}{l}\text { Numbness of } \\
\text { her distal } \\
\text { extremities }\end{array}$ & $\begin{array}{l}\text { Multiple } \\
\text { cerebral } \\
\text { infarctions }\end{array}$ & Presence \\
\hline Shimizu K (9) & $50 /$ male & $35-y-0$ & Leg ulcer & $48-y-0$ & $\begin{array}{l}\text { Double vision } \\
\text { retinal artery } \\
\text { occlusion }\end{array}$ & Not done & Presence \\
\hline Ohtani H (10) & 59/female & $56-y-0$ & $\begin{array}{l}\text { Visual } \\
\text { disturbance }\end{array}$ & $56-y-0$ & $\begin{array}{l}\text { Retinal artery } \\
\text { occlusion }\end{array}$ & $\begin{array}{l}\text { Multiple } \\
\text { cerebral } \\
\text { infarctions }\end{array}$ & Absence \\
\hline Present case & $24 /$ male & $1-y-0$ & $\begin{array}{l}\text { Raynaud's } \\
\text { phenomenon }\end{array}$ & $20-y-0$ & $\begin{array}{l}\text { Hallucination } \\
\text { and dellusion }\end{array}$ & Brain atrophy & $\begin{array}{l}\text { Presence } \\
\text { (IgG-type) }\end{array}$ \\
\hline
\end{tabular}




\section{Psychiatric Disturbance in Sneddon's Syndrome}

vessels involved in the present case seem to be smaller than a small artery. MRI revealed progressive worsening of the cerebral damage and cortical atrophy which probably induced the psychiatric problems. Figs. 4 and 5 show brain MRI performed when he was twenty-three. Seven different types of abnormalities were pointed out as described in the text. Points could be related to the circulatory disturbance due to the narrowing or occlusion of smaller vessels, and points to the secondary atrophic effects. But immunological cross reaction of the antiphospholipid antibody to the myelin components may play a role in the formation of white matter lesions (13).

There is no agreement regarding the detection of antiphospholipid antibodies (14) and the therapy for the antiphospholipid antibody syndrome. Bruyn et al (15) reported a type of Sneddon's syndrome, and the patient continually improved after treatment with cyclophosphamide, with paraneoplastic phenomenon of Hodgkin's disease. However, Rautenberg et al (5) showed that azathioprine did not prevent further cerebrovascular damage and they speculated that immunosuppressive therapy is of limited value to patients without anti-cardiolipin antibody. In the present case, we administrated $400 \mathrm{mg} /$ day of cyclophosphamide intravenously biweekly in addition to $20 \mathrm{mg} /$ day of prednisolone in order to diminish the titer of IgG-class anti-cardiolipin antibody, which might be a major cause of thrombosis. We also administrated $60 \mu \mathrm{g} / \mathrm{day}$ of prostaglandin $\mathrm{I}_{2}$ analogue to prevent contact between the endothelial cells and blood cells. A low dose of haloperidole (2$3 \mathrm{mg} /$ day) in combination with an anti-Parkinson drug was used to alleviate the psychotic symptoms. After the therapy, the anticardiolipin antibody returned to normal, and the psychotic problems disappeared. However, his mental ability remained subnormal and 1-2 $\mathrm{mg} /$ day of haloperidole is necessary to prevent a reappearance of psychotic symptoms. A complete evaluation of the present therapy was difficult in this situation. A further controlled study is necessary to determine when and what type of therapy to start. Dermatologists, neurologists, psychiatrists, and rheumatologists should be aware of the importance of Sneddon's syndrome since it can often be an unrecognized, slowly progressive systemic disease caused by endoarteritis.

\section{References}

1) Kimming J. Arteriolopathie: Livedo rasemosa. Dermatol Wochenschr 139: $211,1959$.

2) Champion RH, Rook A. Livedo reticularis. Proc R Soc Med 53: 961 , 1960.

3) Church RE. Reticular livedo with cerebro-vascular lesions. Br J Dermatol 74: $156,1962$.

4) Sneddon IB: Cerebro-vascular lesions and livedo reticularis. Br J Dermatol 77: 180, 1965.

5) Rautenberg W, Hennerici M, Aulich A, Holzke E, Lakomel HG. Immunosuppressive therapy and Sneddon's syndrome. Lancet ii: 629, 1988.

6) Kalashnikova LA, Nasonov EL, Kushekbaeva AE, Gracheva LA. Anticardiolipin antibodies in Sneddon's syndrome. Neurology 40: 464, 1990.

7) Rebollo M, Val JF, Garijo F, Quintana F, Berciano J. Livedo reticularis and cerebrovascular lesions (Sneddon's syndrome). Clinical radiological and pathological features in eight cases. Brain 106: 965, 1983.

8) Otoyama K, Katayama I, Suzuki Y, Tone T, Nishioka K, Nishiyama S. A case of Sneddon's syndrome with positive ANA and anti-cardiolipin antibodies: Primary anti-phospholipid syndrome? J Dermatol 17: 489, 1990.

9) Shimizu K, Numaga J, Takahashi M, Matsunaga T. A case of Sneddon's syndrome. J Jpn Ophthalmol Soc 99: 104, 1995.

10) Ohtani $H$, Imai $H$, Yasuda $T$, et al. A combination of livedo racemosa, occlusion of cerebral blood vessels, and nephropathy: Kidney involvement in Sneddon's syndrome. Am J Kidney Dis 26: 511, 1995.

11) Zelger B, Sepp N, Schmid KW, Hintner H, Klein G, Fritsch PO. Life history of cutaneous vascular lesions in Sneddon's syndrome. Hum Pathol 23: 668, 1992.

12) Jonas J, Kolble K, Volcker HE, Kaldan JR. Central retinal artery occlusion in Sneddon's disease associated with antiphospholipid antibodies. Am J Ophthalmol 102: 37, 1986.

13) Kaise $S$, Watanabe $H$, Kasukawa R. Crossreactivity of anti-cardiolipin antibodies with glycolopids and endothelial cells. Fukushima J Med Sci 40: $25,1994$.

14) Rousbey RAS. Autoantibodies to phospholipid binding plasma protein: a new view of lipid anticoagulants and other "antiphospholipid" autoantibodies. Blood 84: 2854, 1994.

15) Bruyn RPM, van der Veen JPW, Donker AJM, Valk J, Wolters E Ch. Sneddon's syndrome. Case report and literature review. J Neurol Sci 79: 243, 1987. 